\title{
Tissue for transplantation
}

\author{
Tam Dalyell, MP
}

In this article Mr Tam Dalyell MP uses extracts from the speech ${ }^{1}$ he made in the House of Commons on II December 1974 to reiterate his reasons for persisting in his attempts to have formulated in law the right of hospitals to take such organs from a dead person as might be useful unless before death potential donors (all of us) had stated that they did not consent. Details of those objecting would be registered on a central computer.

Five times since 197 I I have attempted to introduce a Bill (the Human Organs Bill) to make it legal without the consent of relatives or those in charge of a body for 'hospitals to take the organs, such as kidneys, of any patient, once clinical death has been established, other than those of a deceased person who has contracted out during his lifetime by registering, on a central computer, his desire not to donate organs' (Hansard, II December 1974).

My earlier attempts were supported, among others, by two former Secretaries of State for Social Services, Members of Parliament of all parties, and of course by doctors concerned with the various aspects of organ transplantation.

I do not think that I can make my points more cogently to the readers of the fournal of medical ethics than by quoting directly from the speech I made when moving the Bill in the House of Commons on II December 1974. The debate has continued in public and private discussions but the premisses on which I based my arguments in introducing my Bill have not changed.

'The Bill is prompted by the fact that 450 kidneys are transplanted in the United Kingdom each year, whereas 2000 or more people a year need transplants. That figure does not include many young and middle-aged patients who are dying without even so much as the offer of dialysis or transplantation. For want of matching tissue, several transplantation centres have virtually ceased work. I understand from Sir Michael Woodruff, a professor in Edinburgh, that there is not a single unit in the United

1These extracts have been reprinted exactly as they appeared in Hansard on II December I974 when Mr Tam Dalyell introduced his Human Organs Bill. The Bill will not be accepted in this session but a circular is being sent out from the Department of Health and Social Security to all interested bodies.
Kingdom which is working to full capacity or anything like it.'

\section{Why are we short of kidneys?}

'The question arises why we are so short. The most important factor is the attitude of most members of the medical profession. One small district general hospital, where keen young medical staff have transplantation in mind, provides an average of half-a-dozen donors a year - 12 kidneys. Yet many of the largest teaching hospitals, with active transplantation units, including some of the most prestigious in Britain, have provided not a single kidney for transplantation.

It is altogether too easy to blame the doctors. The argument behind the Bill is that if they saw the law in a different light, if it were altered in the direction of contracting out, doctors would be less uneasy and more willing to make organs available.'

\section{Contacting the next-of-kin}

'First, as things stand, a doctor or surgeon has to contact the next-of-kin at the time of maximum grief and to put this awful question, "Can we have the organs of your loved one?" How many of us, if we were doctors, would have the heart to put to a shattered mother or father or a young wife such a question within minutes of their hearing, for example, of a motor smash? Yet if the question is delayed, the organ deteriorates and becomes less useful to someone in need. After an hour, the kidney becomes completely useless.

It is pertinent to add that four of our most distinguished renal surgeons - Barnes, Calne, Hopewell, and Sells - say that the poor quality of kidneys transplanted in the United Kingdom is well known on the Continent, because of the relatively high proportion of organs damaged by ischaemia, as a result of doctors waiting to obtain permission to transplant them.'

\section{The contracting-out situation}

'In a contracting-out situation, as envisaged by the Bill, a telephone call to the computer in Bristol could determine whether a victim had willed "Don't take my organs". Delay and deterioration could then be cut to a minimum. All transplant surgeons can cite 
cases where the relatives at first refused permission and then changed their minds when it was too late. The present system discourages even the most public spirited. It is distressing for the relatives and difficult for the doctors, and it stops lives being saved.'

\section{Uncertainty of the law}

'Secondly, doctors often fear that by being involved in an organ donation they might in some way be contravening the law, with its present uncertainty of interpretation. Despite the issuing of donor cards, very few kidneys have been taken from donors or potential donors carrying cards. Even the carrying of cards became less popular after their legality was questioned in the House, if he will forgive me saying so, by the right hon. Member for Leeds, NorthEast (Sir Keith Joseph). I never had any great hope of the donor card system in the first place, for the very human reason that accidents are things that happen to other people, not to any of us, and therefore many of us forget to carry a card, even if we have one.

Besides, doctors are understandably nervous of the contrasting attitudes among coroners. The Bill takes the view of the Inner West London Coroner, Dr Gavin Thurston, who says that there is seldom difficulty in telling whether a body is likely to be investigated because of the possibility of murder or manslaughter. He argues that in such cases organs should not be removed, as the removal of clothing would interfere with the taking of photographs, which might constitute important evidence. However, in his experience, most cases do not fall within that category. Dr Thurston considers that coroners could give permission for organs to be removed in the majority of accident cases, including those which lead to prosecution for causing death by dangerous driving.'

\section{Accusations of hastening death}

'Thirdly, doctors do not want to be accused of hastening the death of a potential donor. The Bill makes it clear that, before any organ could be removed, clinical death or brain death would have to be certified by two doctors, neither of whom was a member of the transplant team ...

'A survey by me in West Lothian in 1969 showed? that 364 people out of a thousand could go fo contracting-out and 312 for contracting-in, with II6 against, and the balance of 208 being "Don' knows". But there seems to be a shift of opinion, towards kidney donation."

\section{The concern of the public}

'In the spectacular heart operation, public opinion' is concerned with the old concept of 'heart and soul', which is altogether more difficult. The Bill is basically concerned with kidneys.

Determined opposition has come from only on $\overrightarrow{\mathrm{e}}$ source - the Chief Rabbi and his staff, who woulos go for contracting-in but are passionately opposed to contracting-out, on grounds of freedom. I do not want to make a cheap debating point to the Rabbi or the Jewish community, but the most free form of contracting-out in western Europe is in Israel.

Perhaps here we have the example of a legislature such as our own which has rather fallen behindr medical progress.

Of course the wishes of the bereaved must be respected, particularly at a time of extrem $\bar{\emptyset}$ emotional strain. On the other hand, we must rea: lize that every individual refusal could prejudice the lives and futures of two other people who are for the moment still alive but seriously ill. I suspect that the Department is overconcerned with what it thinks may be the wishes of the relatives and underconcerned with the desperate plight of fami lies in need of kidneys.

Let us put ourselves in the position of having $\dot{2}$ child or teenager who will die in the absence of matching tissue. Would not every one of us, aŝ parents, be desperate to find matching tissue for $\mathrm{a}$ child of ours? It is for the young and middle-aged? men and women and their relatives, with thes prospect of useful working lives ahead of them? that I ask the Government to look sympathetically on the substance of the Bill, and the House to give the Bill a Second Reading.'

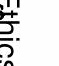

